\title{
Memotret Pandemi: \\ Hoaks COVID-19 dan Paradoks Kemanusiaan ${ }^{1}$
}

\author{
Sri Herwindya Baskara Wijaya, Eka Nada Shofa Alkhajar \\ Universitas Sebelas Maret, Surakarta
}

\section{Pendahuluan}

Organisasi Kesehatan Dunia (World Health Organization, WHO) telah mengumumkan bahwa dunia pada saat ini tengah menghadapi sebuah pandemi. Situasi darurat kesehatan internasional akibat wabah penyakit global ini disebabkan oleh virus baru yang awalnya menyebar di Wuhan, kota kecil di Provinsi Hubei, Republik Rakyat Tiongkok (RRT). Virus ini dikenal sebagai Severe Acute Respiratory Syndrome Coronavirus 2 (SARS-CoV-2). Adapun penyakit yang ditimbulkannya disebut sebagai Coronavirus disease 2019 (COVID-19) (Shmerling, 2020; Sun et al., 2020).

Sebagaimana diketahui, bak gelombang badai yang tak terbendung, COVID-19 kemudian menyebar cepat ke seluruh penjuru dunia. Secara faktual, data per 1 April 2020 yang dirilis Worldometer (2020) menyebutkan sekitar 203 negara telah terjangkiti penyakit mematikan tersebut. Kemudian tercatat pula sebanyak 872.756 orang telah terinfeksi COVID-19 dengan rincian angka kematian sebesar 43.270 orang dan angka kesembuhan mencapai 184.514 orang. Tak pelak, kini dunia dapat ibaratkan tengah dihantui kabut gelap bernama COVID-19 yang membawa resiko di berbagai lini kehidupan terutama pada kesehatan, keamanan dan perekonomian global.

\section{Garda Terdepan}

Di tengah kondisi pandemi ini, para medis terutama dokter dan perawat merupakan garda terdepan dalam aksi penanggulangan COVID-19. Oleh karena itu, potensi mereka tertular penyakit ini sangat besar. Tidak sedikit dari para pahlawan kemanusiaan tersebut yang justru menjadi korban. Bahkan hingga meninggal dunia. Mereka bertarung dan bertaruh nyawa melawan ganasnya penyakit ini dengan merawat para pasien yang terinfeksi COVID-19 atau pasien dalam perawatan (PDP). Di luar itu, masih berjejer banyaknya orang dengan

\footnotetext{
${ }^{1}$ Sumber Naskah:

Wijaya, S. H. B., \& Alkhajar, E. N. S. (2020). Memotret Pandemi: Hoaks Covid-19 dan Paradoks Kemanusiaan. In F. Junaedi (Ed.), Krisis Komunikasi dalam Pandemi Covid-19 (pp. 229-233). Yogyakarta: Buku Litera.
} 
status orang dalam pengawasan (ODP) dan orang dalam resiko (ODR). Baik PDP, ODP maupun ODR tentu memerlukan penanganan medis yang cepat dan tepat jika tidak ingin korban COVID-19 terus bertambah dan bertumbangan.

Demikian pula dengan aparat keamanan yang dituntut untuk siaga total mengawal keamanan di berbagai daerah dan negara. Mereka bekerja penuh waktu mengatur dan memastikan sektor keamanan benar-benar terkendali. Dedikasi dari berbagai pihak lain pun sangat luar biasa utamanya dalam semangat gotong royong dan bergandengan tangan untuk mencegah penyebaran COVID-19. Ini adalah hari-hari mendebarkan di mana solidaritas, kerja sama dan kesadaran bersama sangat dibutuhkan. Semua itu adalah modal penting bagi setiap bangsa untuk memenangi perang melawan pandemi yang memilukan ini.

Meskipun dunia tengah berjuang keras menghadapi pandemi ini, namun ada saja pihak-pihak tertentu yang justru melakukan paradoks kemanusiaan. Mereka seperti memanfaatkan situasi darurat ini untuk mengambil keuntungan di tengah kepanikan dan derita orang lain. Pelaku penimbunan masker adalah salah satu contoh konkrit dari paradoks kemanusiaan tersebut. Kita tentu sedih melihat kenyataan ini. Di satu sisi, banyak pihak yang berjuang untuk kemanusiaan. Namun, di sisi lain justru ada pihak-pihak yang mereduksi dan mendegradasi kemanusiaan. Pihak-pihak tak bertanggungjawab ini terkesan menari-nari di atas penderitaan orang lain. Dalam konteks ini, publik sudah pasti menjadi pihak yang sangat dirugikan karena kesulitan mendapatkan masker. Kelangkaan akibat penimbunan tersebut bahkan menyebabkan harga masker melambung tinggi.

\section{Paradoks Hoaks}

Selain persoalan tersebut, fenomena hoaks (hoax) ikut merajalela di tengah kondisi pandemi ini. Banyak informasi palsu dengan status sebagai disinformasi, misinformasi, maupun malinformasi yang turut memperkeruh situasi penanganan COVID-19. Data Kementerian Komunikasi dan Informatika (Kominfo) Republik Indonesia sebagaimana tercantum dalam Siaran Pers No. 42/HM/Kominfo/03/2020 menyebutkan bahwa per 17 Maret 2020 telah teridentifikasi sebanyak 242 konten hoaks dan disinformasi berkaitan dengan COVID-19 yang beredar di Indonesia. Konten-konten ini tersebar di berbagai platform media sosial, website maupun platform pesan instan (Kominfo, 2020).

Kepolisian Republik Indonesia (Polri) sendiri setidaknya telah menangani 51 kasus konten hoaks terkait COVID-19. Polri telah menindak para penyebar hoaks tentang isu COVID-19 ini dalam 26 hari terakhir atau sebelum 28 Maret 2020 dengan sebaran di Kepolisian Daerah (Polda) Jawa Timur (10 kasus), di Markas Besar (Mabes) Polri (5 kasus), di Polda Kalimantan Barat dan di Polda Lampung (masing-masing 4 kasus) serta di wilayah Polda lain (1-3 kasus) (Wahid, 2020; Nugroho, 2020). 
Sementara itu, Kominfo melaporkan daftar konten hoaks terkait COVID19 di Indonesia, di antaranya seperti: Presiden Jokowi Terinfeksi Virus Corona, Mitra Gojek Suspect Corona Melarikan Diri, Mendagri Tito Karnavian Terkena Corona, Lemon Panas Dapat Membunuh COVID-19, Asap Rokok Mampu Membunuh Corona, Urin Sapi Jadi Obat Virus Corona, Minum Alkohol Mampu Kurangi Resiko Corona, Jutaan Masker Asal Tiongkok Mengandung Corona Dikemas Ulang, Penyembuhan Virus Corona dengan Bawang Putih, Menghirup Uap Panas Bisa Membunuh Virus Corona, dan Amoxilin Dapat Membunuh Virus Corona (Andika, 2020; Kominfo, 2020). Termasuk pula di sini, konten hoaks terkait COVID-19 non domestik yang viral seperti hoaks mengenai Presiden Rusia Vladimir Putin yang melepas singa dan harimau untuk mencegah warga keluar dari rumah di tengah wabah corona (Aida, 2020).

Merebaknya konten hoaks tentu saja membuat kita mengerutkan dahi mengingat publik tentu sangat membutuhkan informasi atau konten akurat di tengah situasi pandemi seperti saat ini. Akan tetapi, yang terhampar justru banyak konten yang ternyata hoaks. Apabila tidak hati-hati, publik tentu saja dapat tertipu dan mempercayai konten-konten hoaks tersebut. Selain itu, efek disfungsi yang lebih dalam dari hoaks ini adalah menimbulkan kecemasan, ketakutan dan kepanikan kolektif. Kondisi tersebut apabila tidak dapat ditanggulangi tentu dapat berakibat buruk dan berpotensi destruktif.

\section{Mengapa Hoaks Mewabah?}

Ada sebuah pertanyaan besar, mengapa hoaks mudah muncul dan tersebar di masyarakat termasuk dalam konteks ini hoaks yang berkaitan dengan COVID19? Sri Herwindya Baskara Wijaya dalam bukunya, Seri Literasi Media: Dari Hoax hingga Hacking (2019) menyebut ada sejumlah alasannya. Salah satu di antaranya adalah kecanggihan teknologi komunikasi dan penguasaan keterampilan teknis penggunaan teknologi ternyata tidak berbanding lurus dengan kompetensi etis di kalangan sebagian warga internet. Akhirnya yang terjadi, produksi hoaks semakin menjamur baik warga internet paham atau tidak paham dalam memproduksinya.

Dalam konteks ini, ponsel pintar (smartphone) menempati rating tertinggi sebagai bentuk teknologi informasi dan komunikasi (TIK) yang paling banyak digunakan publik. Data We Are Social dan Hootsuite (2020), misalnya, mencatat per Januari 2020 sebanyak 175,4 juta atau hampir 64 persen penduduk Indonesia telah terkoneksi dengan jaringan internet. Meskipun demikian, angka pengguna internet ini faktanya jauh lebih besar di lapangan. Hal ini dikarenakan penduduk Indonesia banyak mengakses internet melalui perangkat mobile seperti smartphone atau tablet di mana angkanya tercatat sebanyak 338,2 juta pengguna. 
Ihwal ini semakin menegaskan bahwa penggunaan internet merupakan bagian penting dari identitas kemodernan (Alkhajar, 2014).

Kemudian, alasan lain menjamur dan tersebarnya hoaks adalah karena kemalasan berpikir atau verifikasi. Banyak warga internet yang tidak benar-benar membaca secara kritis konten yang didapatkan tetapi langsung membagikan dan menyebarkannya padahal konten tersebut adalah hoaks. Selain itu, warga internet juga mudah percaya terhadap konten hanya karena mereka percaya kepada sumber pengirim konten ataupun cepat percaya kepada konten apapun yang dianggap memiliki kaitan dengan sumber berita resmi tanpa melakukan pengecekan ulang.

Ditambah lagi, persebaran hoaks bersifat sporadis dan tidak mudah diredam karena langsung bersentuhan dengan individu-individu warga internet di ruang-ruang privasi. Kondisi ini makin diperparah dengan umpan balik negatif berupa komentar bernuansa ujaran kebencian (hate speech) sehingga makin meruyamkan keadaan. Sebagaimana ditekankan oleh seorang peneliti, hoaks apabila tidak segera diatasi dapat menjadi bom waktu yang berbahaya bagi kelangsungan dan ketenteraman masyarakat. Terlebih, hoaks yang memang sulit dilacak kebenarannya justru sangat cepat tersebar dan viral di berbagai media sosial sehingga berpotensi memicu kegaduhan, keresahan, dan bahkan konflik manifes yang kontraproduktif (Ali, 2017: 93).

\section{Penutup}

Satu hal yang pasti, hoaks merupakan asupan buruk dan tidak sehat bagi kesehatan informasi publik. Di tengah pandemi seperti saat ini, kesadaran bersama menjadi tuntutan penting bagi semua pihak termasuk dalam perilaku berinformasi publik. Dengan tidak memproduksi atau membagikan informasi-informasi yang tidak jelas kebenarannya terkait COVID-19, sesungguhnya kita telah meneguhkan esensi kemanusiaan sekaligus menyelamatkan publik dari paradoks kemanusiaan. Tabik.

\section{Daftar Pustaka}

Aida, N. R. (2020, March 22). [HOAKS] Putin lepaskan singa untuk cegah warga keluar rumah saat wabah Corona. Kompas.com. Retrieved March 31, 2020, from https://www.kompas.com/tren/read/2020/03/22/194600765/hoaks-putinlepaskan-singa-untuk-cegah-warga-keluar-rumah-saat-wabah-corona

Ali, M. (2017). Antara komunikasi, budaya dan hoax. In A. Wahyudin \& M. Sunuantari (Eds.), Melawan hoax di media sosial dan media massa (pp. 89-107). Yogyakarta: Trustmedia Publishing. 
Alkhajar, E. N. S. (2014). Media, masyarakat dan realitas sosial. Surakarta: Sebelas Maret University Press.

Andika, F. (2020, March 17). 36 hoax baru tentang virus Corona di internet, apa saja? Indozone.id. Retrieved March 31, 2020, from https://www.indozone.id/tech/N4sDXy/36-hoax-baru-tentang-viruscorona-beredar-di-internet-apa-saja/read-all

Kominfo. (2020). Siaran Pers No. No. 42/HM/Kominfo/03/2020 Kawal Informasi Covid-19, Kominfo Identifikasi 242 Konten Hoaks, 17 Maret 2020. Kementerian Komunikasi dan Informatika (Kominfo), Jakarta.

Nugroho, A. (2020, March 28). 51 Penyebar Hoax Corona Lewat Medsos Diproses Hukum oleh Aparat Kepolisian. Kompas.tv. Retrieved March 31, 2020, from https://www.kompas.tv/article/73462/51-penyebar-hoaxcorona-lewat-medsos-diproses-hukum-oleh-aparat-kepolisian

Shmerling, R. H. (2020, March 16). Be careful where you get your news about coronavirus. Harvard Health Blog. Retrieved March 31, 2020, from https://www.health.harvard.edu/blog/be-careful-where-you-get- your-

news-about-coronavirus-2020020118801

Sun, K., Chen, J., \& Viboud, C. (2020). Early epidemiological analysis of the Coronavirus disease 2019 outbreak based on crowdsourced data: A popularion-level observational study. Lancet Digital Health, 2: e201208.

Wahid, A. B. (2020, March 27). Polri tangani 51 kasus hoax terkait Corona. Detiknews.com. Retrieved March 31, 2020, from https://news.detik.com/berita/d-4955976/polri-tangani-51-kasus-hoaxterkait-corona

We Are Sosial \& Hootsuite. (2020). Digital 2020: Indonesia. Datareportal.com. Retrieved March 31, 2020, from https://datareportal.com/reports/digital-2020-indonesia

Wijaya, S. H. B. (2019). Seri literasi media: Dari hoax hingga hacking. Yogyakarta: Buku Litera.

Worldometer. (2020). COVID-19 Coronavirus Pandemic. Worldometers.info. Retrieved April 1, 2020, from https://www.worldometers.info/coronavirus/

\section{Sumber Naskah:}

Wijaya, S. H. B., \& Alkhajar, E. N. S. (2020). Memotret Pandemi: Hoaks Covid19 dan Paradoks Kemanusiaan. In F. Junaedi (Ed.), Krisis Komunikasi dalam Pandemi Covid-19 (pp. 229-233). Yogyakarta: Buku Litera. 